Pedagogik Jurnal Pendidikan, Maret 2014, Volume 9 Nomor 1, (9-38)

\title{
IMPLEMENTASI PENDIDIKAN KARAKTER TERHADAP PELAJARAN IPA DI MIS HIDAYATUL INSAN PALANGKA RAYA
}

\author{
Oleh : Nurul Hikmah Kartini *
}

\begin{abstract}
Abstrak
Penelitian ini bertujuan untuk mengetahui dan mendapatkan data dalam penerapan pendidikan karakter terhadap pelajaran IPA pada peserta didik kelas V. Penelitian ini dilaksanakan di MIS Hidayatul Insan, Kota Palangka Raya.

Metode yang digunakan dalam penelitian ini adalah metode kualitatif yang pada umumnya menggunakan teknik observasi untuk memperkuat data, wawancara untuk mengadakan komunikasi dengan para informan atau objek penelitian, dan studi dokumenter (dokumentasi) untuk mengumpulkan data yang bersumber dari arsip yang berada di dalam sekolah maupun yang berada di luar sekolah. Atas dasar konsep itu maka ketiga teknik pengumpulan data di atas digunakan dalam penelitian ini.

Hasil penelitian: Kepala Sekolah dan Para Guru di MIS Hidayatul Insan Palangka Raya sangat tertarik untuk menerapkan pendidikan karakter dimana sekolah menyediakan sarana dan prasarana berupa silabus, RPP, dan buku pelajaran peserta didik sehingga dalam proses pembelajarannya dapat memudahkan guru dan sejak diterapkannya pendidikan karakter sudah dapat meningkatkan hasil belajar atau prestasi peserta didik. Dari hasil penelitian di atas dapat diketahui bahwa kondisi dari peserta didik juga menentukan dalam penerapan pendidikan karakter dan pembelajaran.
\end{abstract}

\section{Kata Kunci : Pendidikan Karakter}

\section{PENDAHULUAN}

Kemajuan Ilmu Pengetahuan dan Teknologi (IPTEK) dalam dunia pendidikan dewasa ini memang sangat pesat dan membanggakan terbukti dengan banyak ditemukannya berbagai inovasiinovasi baru yang dapat mempermudah suatu pekerjaan atau meringankan beban manusia. Hal ini tentunya juga mempunyai efek positif dan negatif dan harus menjadi perhatian orang tua untuk selalu memantau anak-anaknya dalam menggunakan kecanggihan teknologi sekarang ini. Peran orang tua, sekolah dan masyarakat akan membentuk watak dan kepribadian anak. Apabila seorang anak hidup dalam keadaan dan lingkungan yang baik maka dengan sendirinya juga akan membentuk karakter dan watak anak itu menjadi baik. Sebaliknya apabila seorang anak hidup dalam lingkungan yang kurang baik maka karakter dan wataknya juga akan kurang baik. Dengan demikian ketiga komponen tadi keluarga, sekolah dan masyarakat harus menjadi benteng yang kuat dan kokoh dalam menghadapi dunia globalisasi.

Berdasarkan ketiga komponen dasar pendidikan di atas sekolah yang paling bertanggung jawab dalam membentuk watak dan karakter peserta didik. Karena di sekolah sebagian besar peserta didik menghabiskan waktunya untuk mengenyam pendidikan dan menimba ilmu pengetahuan. Maka dari itu apabila karakter peserta didik menyimpang dari yang diharapkan siapa yang disalahkan, Megawangi (2004). Dari situlah peran guru sangat dibutuhkan, disatu sisi peran orang tua dan lingkungan masyarakat juga sangat berpengaruh untuk membentuk kepribadian 
peserta didik yang berwawasan dan berakhlak.

Selama ini saat mengamati kegiatan belajar mengajar di sekolah materi dan nilai pendidikan karakter cenderung hanya diajarkan pada saat pelajaran Pendidikan Agama dan Pendidikan Kewarganegaraan (PKN) sehingga mereduksi aplikasinya hanya sebatas pada ranah etika. Padahal, konsepsi pendidikan karakter menuntut penjabaran lebih komprehensif, Sahlan dan Prasetyo (2012). Akibatnya, pendidikan karakter belum mampu mewarnai mentalitas peserta didik dalam mengikuti pembelajaran di dalam kelas. Contohnya, dalam pelajaran ilmu pengetahuan alam (IPA) peserta didik masih banyak yang berkeliaran, mengganggu temannya, lari kesana kemari dan bahkan menyontek pada saat mengerjakan soal dan masih banyak yang lainnya. Akan tetapi, hal itu tidak sepenuhnya kesalahan peserta didik karena sikap dan perilaku guru juga berpengaruh pada watak dan karakter peserta didik. Misalnya, kurang disiplinnya guru ketika datang ke sekolah dan masuk kelas, cara berbicara dan bergaulnya antar guru, ditambah keberadaan kantin dan penjual jajanan yang berada di luar areal sekolah yang terkadang guru dan peserta didik makan dan minum bersamaan dalam satu kantin. Apabila ini terus terjadi, maka akan berpengaruh pada kepribadian peserta didik dan perilaku seperti ini secara sendirinya akan diikuti peserta didik.

Hal ini menjadikan seakan-akan ruh pendidikan karakter yang telah ditanamkan pada mata pelajaran Agama dan PKN tersebut, tidak bisa berbuat banyak pada mata pelajaran lainnya. Itulah mengapa pendidikan karakter sepertinya hanya bisa berbicara jauh dalam tataran kawasan teoritis, tetapi membisu saat akan diterjemahkan dalam kehidupan sehari-hari.
Meskipun diantara peserta didik, guru, dan pemangku pendidikan lainnya mengetahui bahwa pendidikan karakter itu penting bagi kehidupan, implementasinya masih dikatakan "jauh dari harapan”. Pembelajaran dan pendidikan karakter masih terdominasi ke dalam ranah kognitif sehingga membutuhkan perluasan domain. Peserta didik yang begitu hafal dengan konsepsi nilai-nilai luhur agama, kebudayaan, dan kebangsaan yang terbungkus ke dalam pendidikan karakter, seringkali kurang dapat menyerap kemanfaatannya. Apalagi ada hal lain yang terjadi yaitu, setiap ganti semester peserta didik terkadang lupa dengan konsep pelajaran yang telah diterimanya. Belum lagi, peserta didik juga jarang di kenalkan dengan hikmah dan nilai-nilai yang menjadi landasan moral pendidikan karakter.

Untuk itu, pembelajaran dan pendidikan karakter harus dikenalkan kembali sebagai mata dan nilai yang terintegrasi dan tersusun dalam berbagai mata pelajaran. Sebab, dominasi ranah kognitif selama ini, hanya mampu bekerja mengukur kecepatan, mengukur hal-hal baru, menyimpan dan mengingat kembali informasi objektif serta berperan aktif dalam menghitung angka (Sahlan dan Prasetyo, 2012).

Dengan demikian, kata kunci bagaimana pendidikan karakter mampu mengatasi krisis masyarakat global adalah menjadi guru dalam perubahan. Karakter perubahan menjadi urat nadi setiap manusia dalam membentuk tatanan masyarakat global yang utuh. Tidak bisa dipungkiri, bahwa untuk memahami zaman, waktu, situasi dan kondisi memerlukan perangkat keilmuan. Sebagai seseorang yang kehidupannya sehari-hari bergelut dengan keilmuan, semua guru seharusnya menjadi sosok yang terdepan. Ia bukan seorang 
dukun yang menangkap fenomena dengan penjelasan berbau klenik atau kerangka pemikiran diluar nalar kebiasaan. Ia yang mengawali mengajarkan membaca fenomena dengan pola pikir yang sistematis dan holistik. Pribadi guru yang demikian, memiliki komitmen serius dalam menyebarkan benih-benih perubahan. Juga menjadi "ibu" yang mampu melahirkan jutaan manusia yang cinta peradaban.

Sahlan dan Prasetyo (2012) mengemukakan bahwa Pendidikan karakter merupakan upaya transformatif pengetahuan dan nilai-nilai luhur yang bersumber dari agama, budaya, dan kebangsaan. Oleh karena itu, jaringan nilainilai pendidikan karakter tersebut dapat dikatakan sebagai circle of instruction yang mempunyai maksud bahwa pendidikan karakter sebenarnya telah tergambar jelas desain pembelajarannya, mulai dari segi materi, proses hingga penilaiannya. Oleh karenanya, pendidikan karakter perlu dikaitkan sebagai bagian dari nilai dan budaya generasi muda Indonesia sehingga menjadi pola sikap kultur dalam membangun peradapan bangsa. Dengan demikian, potensi pendidikan karakter menjadi pola hidup masyarakat Indonesia, dapat kian membesar.

Sebagai bagian dalam mewujudkan peradaban bangsa, kecerdasan yang dimiliki peserta didik sekarang sudah sepatutnya diperkaya dengan berbagai muatan pendidikan karakter seperti sikap religius, kejujuran, mandiri, dan cinta damai. Model seperti inilah yang membentuk peserta didik menjadi manusia seutuhnya. Cakap dalam menganalisis persoalan, namun juga bijaksana dalam bertindak.

Pada dasarnya sekolah yang akan peneliti teliti ini sudah melakukan atau melaksanakan pembelajaran dengan menggunakan pendidikan karakter yaitu, dalam proses belajar mengajar para guru sudah menggunakan rencana pelaksanaan pembelajaran (RPP) karakter. Akan tetapi, hasilnya belum mampu mengubah karakter peserta didik menjadi baik dan menerapkannya dalam kehidupan seharihari. Dengan demikian, untuk mengubah sikap dan karakter peserta didik ketika mengikuti pembelajaran IPA guru harus mengubah paradigma dari mengajar menjadi mendidik atau dalam setiap pertemuan guru menunjukkan bahwa "di balik" materi yang diajarkan, minimal ada satu nilai kehidupan yang baik bagi peserta didik untuk diketahui, dipikirkan, direnungkan dan diyakini sebagai hal yang baik dan benar sehingga mendorongnya untuk melaksanakan dalam kehidupannya. Khusunya pada mata pelajaran IPA guru menekankan pentingnya nilai: kebenaran, ketelitian, keuletan, ketekunan, dan lainlain dalam kehidupan sehari-hari (Adisusilo 2012).

Pendidikan adalah suatu proses enkulturasi, berfungsi mewariskan nilainilai dan prestasi masa lalu kegenerasi mendatang. Selain mewariskan, pendidikan juga memiliki fungsi untuk mengembangkan nilai-nilai budaya dan prestasi masa lalu itu menjadi budaya bangsa yang sesuai dengan kehidupan masa kini dan masa yang akan datang, serta mengembangkan prestasi baru yang menjadi karakter baru bangsa. Oleh karena itu, pendidikan budaya dan karakter bangsa merupakan inti dari suatu proses pendidikan (Wirotomo : 2011).

Bagaimanapun juga kurangnya karakter, sikap, dan tingkah laku peserta didik dalam mengikuti pelajaran IPA. Teori dan didukung dengan pengalaman dalam pembelajaran seorang guru diharapkan dapat memberikan suri tauladan yang baik 
dan mengimplementasikan nilai-nilai karakter dalam kehidupan sehari-hari.

Melalui penjelasan latar belakang di atas dan kenyataan di lapangan serta hasil observasi dalam proses belajar mengajar IPA di kelas $\mathrm{V}$ MIS Hidayatul Insan Palangka Raya yang karakter peserta didiknya masih jauh dari yang di harapkan dan untuk mengetahui adanya penghambat dalam penerapan pendidikan karakter. Dengan demikian peneliti mencoba melakukan penelitian karakter peserta didik kelas $\mathrm{V}$ dalam mengikuti proses belajar mengajar didalam kelas, dengan judul "Implementasi Pendidikan Karakter Terhadap Mata Pelajaran IPA di MIS Hidayatul Insan".

\section{KAJIAN TEORI}

\section{A. Deskripsi Konseptual Fokus Penelitian}

1. Pengertian Ilmu Pengetahuan Alam (IPA)

Sebelum melangkah jauh dalam pembahasan penelitian terlebih dahulu di kemukakan pengertian dari ilmu pengetahuan alam (IPA). Untuk memudahkan pemahaman tersebut, berikut akan di ungkapkan pengertian dari ilmu pengetahuan alam (IPA). "IPA merupakan ilmu pengetahuan yang mengkaji gejala-gejala alam semesta, termasuk dimuka bumi ini sehingga berbentuk konsep-konsep dan prinsip-prinsip dasar Esensial alam, Herabudin (2010:102)". Sedangkan menurut Trianto, (2010:136) "IPA adalah suatu kumpulan teori yang sistematis, penerapannya secara umum terbatas pada gejala-gejala alam, lahir dan berkembang melalui metode ilmiah seperti observasi dan eksperimen serta menuntut sikap ilmiah seperti rasa ingin tahu, terbuka, jujur, dan sebagainya".

Berdasarkan penjelasan diatas dapat disimpulkan bahwa IPA adalah ilmu yang mempelajari gejala-gejala alam secara sistematis melalui metode ilmiah seperti observasi dan eksperimen serta menuntut sikap ilmiah seperti ingin tahu, terbuka, jujur, dan sebagainya. Dengan demikian ttuk mempelajari ilmu IPA hnm. un. yak melakukan studi dan .....gamatan untuk dapat menangkap fenomena atau gejala-gejala yang terjadi baik di alam semesta maupun yang terjadi di bumi.

\section{a. Hakikat ilmu pengetahuan alam}

Pada hakikatnya IPA
dibangun atas dasar produk
ilmiah, proses ilmiah, dan sikap
ilmiah. Selain itu, IPA dipandang pula sebagai proses, sebagai produk, dan sebagai prosedur. Menurut Marsetio Danusapoetro (Trianto, 2010). Sebagai proses diartikan semua kegiatan ilmiah untuk menyempurnakan pengetahuan tentang alam maupun untuk menemukan pengetahuan baru. Sebagai produk diartikan sebagai hasil proses, berupa pengetahuan yang diajarkan dalam sekolah atau di luar sekolah ataupun bahan bacaan untuk penyebaran atau dissiminasi pengetahuan. Sebagai prosedur dimaksudkan adalah metodologi atau cara yang dipakai untuk mengetahui 
sesuatu (riset pada umumnya) yang lazim disebut metode ilmiah (scientific method).

b. Fungsi Pembelajaran IPA

Berikut ini fungsi dan tujuan

IPA menurut Trianto (2010:150)

1. Memberikan pengetahuan tentang berbagai jenis lingkungan alam dan lingkungan buatan yang berkaitan dengan pemanfaatan bagi kehidupan sehari-hari.

2. Mengembangkan keterampilan proses.

3. Mengembangkan wawasan, sikap dan nilai yang berguna bagi peserta didik untuk meningkatkan kualitas pendidikan sehari-hari.

4. Mengembangkan kesadaran tentang adanya hubungan keterkaitan yang saling mempengaruhi antara kemajuan IPA dan teknologi dengan keadaan lingkungan disekitarnya dan pemanfaatannya bagi kehidupan sehari-hari.

5. Mengembangkan kemajuan untuk menerapkan ilmu pengetahuan dan teknologi (IPTEK), serta keterampilan yang berguna dalam kehidupan sehari-hari maupun untuk melanjutkan pendidikannya ketingkatan pendidikan yang lebih tinggi.

\section{c. Tujuan Pembelajaran IPA}

1. Memahami konsep-konsep IPA dan keterkaitannya dengan kehidupan seharihari.
2. Memiliki keterampilan proses untuk mengembangkan proses, untuk mengembangkan pengetahuan, dan gagasan tentang alam sekitar.

3. Bersikap ingin tahu, kritis, bertanggung jawab, bekerjasama, dan mandiri.

4. Mampu menerapkan berbagai konsep IPA untuk menjelaskan gejala alam dan memecahkan masalah dalam kehidupan sehari-hari.

5. Mampu menggunakan teknologi sederhana yang berguna untuk memecahkan suatu masalah yang ditemukan dalam kehidupan sehari-hari.

6. Mengenal dan memupuk rasa cinta terhadap alam sekitar sehingga menyadari kebesaran dan keagungan Tuhan Yang Maha Esa.

\section{d. Manfaat Pembelajaran IPA}

Berikut manfaat pembelajaran

IPA menurut Herabudin

(2010:10).

1. Membantu siswa belajar mengembangkan pikirannya.

2. Memberikan kesempatan kepada siswa untuk melakukan penemuan.

3. Meningkatkan daya ingat.

4. Memberikan kepuasan intrinsik bila anak telah berhasil melakukan sesuatu.

5. Membantu siswa mempelajari konsep-konsep sains.

\section{Pengertian Implementasi dan Pendidikan Berkarakter}


Menurut Susilo (Nahartyo, 2012) implementasi adalah suatu penerapan ide, konsep, kebijakan, atau inovasi dalam suatu tindakan praktik sehingga memberikan dampak, baik berupa perubahan pengetahuan, keterampilan maupun nilai dan sikap. Pada dasarnya setiap metode atau cara pengajaran di sekolah itu sama. Tergantung bagaimana seorang guru dapat mengimplikasikannya atau menerapkannya pada setiap proses pembelajaran. Oleh karena itu, guru dituntut untuk dapat menguasai materi yang akan disampaikan di depan kelas dengan baik agar peserta didik dapat menerima apa yang disampaikan guru dengan mudah dan menyenangkan. Dengan pendekatan pendidikan berkarakter yang saat ini sedang gencar digunakan dalam setiap sekolah dengan harapan dapat mempermudah guru dalam melakukan proses belajar mengajar di dalam kelas. Berikut pengertian karakter menurut para ahli.

\section{a. Pendidikan Berkarakter}

Kata karakter berasal dari kata yunani, charassain, yang berarti mengukir sehingga berbentuk pola. Artinya, mempunyai karakter yang baik adalah tidak secara otomatis dimiliki oleh setiap manusia begitu ia dilahirkan, tetapi memerlukan proses panjang melalui pengasuhan pendidikan proses "pengukiran". Oleh karena itu pendidikan karakter adalah "usaha aktif untuk membentuk kebiasaan baik, sehingga sifat anak sudah terukir sejak kecil" (Megawangi, 2009:5).

Undang-Undang RI No. 20 Tahun 2003 Tentang Sistem Pendidikan Nasional Pasal 3 Menyebutkan Bahwa:

Pendidikan nasional berfungsi mengembangkan kemampuan dan membentuk karakter serta peradaban bangsa yang bermartabat dalam rangka mencerdaskan kehidupan bangsa, bertujuan untuk berkembangnya potensi peserta didik agar menjadi manusia yang beriman dan bertakwa kepada tuhan yang maha esa, berakhlaq mulia, sehat berilmu, cakap, kreatif, mandiri dan menjadi warga Negara yang demokratis serta bertanggung jawab.

Sedangkan ahli pendidikan nilai Darmiyati Zuchdi (Adisusilo, 2012:77) memaknai watak (karakter) sebagai "seperangkat sifat-sifat yang selalu dikagumi sebagai tanda-tanda kebaikan, kebajikan, dan kematangan moral seseorang".

Berdasarkan paparan diatas dapat disimpulkan bahwa karakter adalah sifat bawaan yang dimiliki seseorang ketika ia dilahirkan yang bertujuan untuk mengembangkan potensi diri agar menjadi manusia yang beriman dan bertakwa kepada tuhan yang maha esa.

Selain itu, pendidikan karakter adalah sebuah usaha untuk mendidik peserta didik 
Pedagogik Jurnal Pendidikan, Maret 2014, Volume 9 Nomor 1, (9-38)

secara bijak dan mempraktikkannya dalam kehidupan sehari-hari, sehingga mereka dapat memberikan kontribusi yang positif kepada lingkungannya. Nilai-nilai karakter yang perlu ditanamkan kepada peserta didik adalah nilai-nilai universal yang mana nilai-nilai ini ada pada seluruh agama, tradisi, dan budaya. Berikut adalah nilai-nilai yang selayaknya diajarkan kepada peserta didik di sekolah menurut Megawangi (2004:93):

1. Cinta Tuhan dan segenap ciptaannya

2. Kemandirian dan tanggung jawab

3. Kejujuran, amanah, dan bijaksana

4. Hormat dan santun

5. Dermawan, suka menolong dan gotong royong

6. Percaya diri, kreatif, dan pekerja keras

7. Kepemimpinan dan keadilan

8. Baik dan rendah hati

9. Toleransi, kedamaian dan kesatuan

Pada masyarakat

Indonesia yang heterogen, nilainilai karakter yang ditanamkan harus dapat menjadi dasar kesamaan nilai yang akan menjadi perekat pada elemenelemen masyarakat yang berbeda, sehingga masyarakat dapat hidup berdampingan secara damai dan tertib, yang akhirnya menciptakan suasana sinergi yang sangat produktif bagi kemajuan bangsa. Akan tetapi, pada dasarnya nilai karakter yang cocok untuk bangsa Indonesia adalah nilainilai yang terkandung dalam pancasila.

b. Ciri-Ciri Pendidikan Karakter Berikut ini adalah ciri-ciri pendidikan karakter menurut Adisusilo (2012:78).

1. Keteraturan interior dimana setiap tindakan diukur berdasarkan seperangkat nilai.

2. Koherensi yang memberi keberanian, yang membuat seseorang teguh pada prinsip, tidak mudah terombang-ambing pada situasi

3. Menginternalisasikan nilainilai dari luar sehingga menjadi nilai-nilai pribadi, menjadi sifat yang melekat, melalui keputusan bebas tanpa paksaan dari orang lain.

4. Keteguhan dan kesetiaan.

Berdasarkan ciri-ciri pendidikan karakter di atas peneliti menyimpulkan bahwa, untuk melaksanakan pendidikan karakter yang baik guru dituntut untuk dapat mengoptimalkan kemampuannya dalam menerapkan pendidikan karakter ketika mengajar dan dapat memberikan suri tauladan yang baik pula agar sikap yang baik ini dapat dicontoh oleh peserta didik dan diterapkan dalam kehidupan sehari-hari.

c. Prinsip-Prinsip Pendidikan Berkarakter 
Dibawah ini adalah prinsip pendidikan karakter menurut Lickona (Adisusilo, 2011:81).

1. Pendidikan berkarakter harus mengandung nilainilai yang dapat membentuk "good character".

2. Karakter harus didefinisikan secara menyeluruh yang termasuk aspek perasaan, pikiran, dan prilaku.

3. Gunakan pendekatan yang komprehensif, disengaja ,dan proaktif.

4. Ciptakan komunitas sekolah yang penuh perhatian

5. Buat kurikulum akademik yang bermakna dan yang menghormati semua peserta didik.

6. Beri peserta didik kesempatan untuk melakukan tindakan moral.

7. Mendorong motivasi peserta didik

8. Melibatkan seluruh civitas sekolah sebagai komunitas pembelajaran dan moral.

9. Pendidikan di sekolah memerlukan kepemimpinan moral dari berbagai pihak: pimpinan, staf, dan para guru.

10. Sekolah harus bekerja sama dengan orang tua murid dan masyarakat sekitar.

11. Evaluasi karakter sekolah, fungsi staf sekolah sebagai pendidik karakter, sejauh mana peserta didik mengimplikasikannya dalam kehidupan sehari-hari.

Berdasarkan prinsipprinsip pendidikan karakter di atas peneliti menyimpulkan bahwa kunci keberhasilan penerapan pendidikan karakter adalah adanya kerjasama yang baik antara guru dan orang tua dengan memahami peran dan tugas masing-masing untuk selalu mengawasi perkembangan peserta didik di sekolah, di rumah, maupun di masyrakat.

d. Kelebihan dan Kelemahan Pendidikan Karakter

Adapun kelebihan dan kelemahan pendidikan karakter sebagai berikut menurut Megawangi (2004:23):

1. Peserta didik dapat kreatif dan inovatif

2. Peserta didik menjadi berakhlak mulia

3. Tidak membedakan derajat masing-masing peserta didik, yang membedakan adalah bagaimana peserta didik mampu mengoptimalkan potensi mereka masing-masing.

4. Guru lebih dipacu untuk mengasah kemampuannya sebagai peningkatan profesionalisme secara terus menerus.

Adapun kelemahan pendidikan karakter sebagai berikut:
1. Pengintegrasian mata pelajaran dapat membingungkan peserta didik.

2. Tidak semua guru bisa menggunakan pendekatan pendidikan karakter 
Pedagogik Jurnal Pendidikan, Maret 2014, Volume 9 Nomor 1, (9-38)

3. Terlalu banyak proses sehingga hasil cendrung diabaikan

3. Implementasi

Berkarakter

Pendidikan

Pelajaran (IPA)

Perkembangan

zaman

menyebabkan segala sesuatu terasa kompleks. Demikian pula dalam pembelajaran. Semakin derasnya arus informasi menyebabkan model pembelajaran yang digunakan rupanya tidak cukup jika hanya mengandalkan salah satu keilmuan. Seperti yang dijelaskan dalam latar belakang bahwa kemajuan dan perkembangan IPTEK dewasa ini sudah sangat pesat khususnya dalam sains (IPA). Tetapi, hal ini tidak akan berarti tanpa adanya integrasi di antara mata pelajaran yang ada dengan nilai-nilai pendidikan karakter.

"Implementasi pembelajaran dalam pendidikan karakter tersebut diselenggarakan secara terintegrasi bersamaan pembelajaran setiap mata pelajaran, agar terjadi internalisasi dan personalisasi ke dalam diri peserta didik. Pengintergrasiannya dengan memperhatikan aspek siklus kehidupan, mulai dari lingjungan keluarga, sekolah, dan masyarakat",( DEPDIKNAS, 2012)

Sebagaimana yang dijelaskan Majid dan Andayani (Sahlan dan Prasetyo, 2012:135) beberapa fungsi karakter dalam pembelajaran meliputi hal-hal berikut.

1. Pengembangan. Hal ini mempunyai pengertian bahwa pendidikan karakter mempunyai fungsi untuk menumbuhkembangkan lebih lanjut sifat keimanan dan ketakwaan dalam diripeserta didik secara lebih optimal melalui bimbingan, pengajaran, dan pelatihan.

2. Penanaman nilai. Fungsi pendidikan dalam tataran ini berarti menjadi pedoman hidup peserta didik dalam meniti kehidupan di dunia dan akhirat.

3. Penyesuaian mental. Mengandung pengertian bahwa pendidikan karakter merupakan pembekalan kepada peserta didik untuk dapat meyesuaikan diri dengan lingkungan di sekolah, keluarga, dan masyarakat.

4. Perbaikan. Hal ini mengandung arti bahwa fungsi pendidikan karakter mempu membawa peserta didik untuk memperbaiki kealahan, kekarangan, dan kelemahan dalam keyakinan, pemahaman, dam pengalaman dalam kehidupan sehari-hari.

5. Pencegahan. Hal ini menandaskan bahwa pendidikan karakter mempunyai fungsi untuk menghindari hal-hal negative yang berasal dari lingkungan atau dari budaya lain.

6. Pengajaran. Hal ini mengandung arti bahwa peserta didik mendapat pengajaran dan pendidikan karakter secara umum mengenai nilai dan manfaatnya.

7. Penyaluran. Peserta didik yang memiliki bakat khusus diarahkan untuk dapat berkembang secara optimal sehingga dapat dimanfaakan 
untuk dirinya sendiri maupun orang lain. Dengan demikian pendidikan berkarakter sudah seharusnya ditanamkan pada setiap mata pelajaran yang diajarkan sekolah.

Berdasarkan

fungsi pendidikan karakter di atas peneliti menyimpulkan bahwa dalam penerapan pendidikan karakter pada mata pelajaran, guru harus dapat menggunakan berbagai media dan mengetahui bagimana karakter peserta didik itu sendiri sehingga akan mempermudah guru dalam menyampaikan materi dan proses pembelajaran akan berjalan dengan baik.

Menurut Sahlan dan Prasetyo (2012) Pelaksanaan pembelajaran dan pendidikan karakter setiap hari dilakukan dengan menggunakan tiga tahapan: (1) kegiatan pendahuluan/pembukaan. Kegiatan ini dilakukan terutama untuk menciptakan suasana awal pembelajaran berupa kegiatan untuk pemahaman. Kegiatan pembukaan mempunyai pengaruh kuat dalam kesuksesan pembelajaran. Diusahakan agar dalam membuka awal pembelajaran, guru sebisanya membuat nyaman peserta didik. (2) kegiatan inti. Dalam kegiatan tersebut, difokuskan pada kegiatankegiatan yang bertujuan mengembangkan kemampuan penghayatan keimanan, pemahaman, dan pengamalan. (3) kegiatan penutup. Sifat dari kegiatan ini adalah untuk menenangkan. Kegiatannya berupa menyimpulkan/ mengungkapkan hasil pembelajaran yang telah dilakukan bersama-sama antara guru dan peserta didik.

\section{Penghambat dalam Implementasi Pendidikan Berkarakter}

Pelaksanaan pendidikan berkarakter yang diselenggarakan di sekolah dapat berlangsung secara lancar, tetapi ada juga kemungkinan implementasinya menjadi gagal. Hal itu terjadi karena terdapat beberapa faktor yang mempengaruhinya. Jika di kelompokan faktor-faktor yang mempengaruhi implementasi pendidikan berkarakter di sekolah dapat dibedakan menjadi dua kelompok, yaitu faktor internal dan faktor eksternal. Berikut penjelasannya menurut (Slameto, 2010).

a. Faktor internal adalah faktor yang ada dalam diri individu yang sedang belajar. Faktorfaktornya sebagai berikut:

1. Intelegensi

Intelegensi adalah kecakapan yang terdiri dari tiga jenis yaitu kecakapan untuk menghadapi dan menyesuaikan kedalam situasi yang baru dengan cepat dan efektif. Artinya, peserta didik yang mempunyai tingkat inntelegensi yang normal dapat berhasil dengan baik dalam belajar. Sebaliknya, jika peserta didik yang memiliki intelegensi yang rendah, ia perlu mendapat pendidikan di lembaga pendidikan khusus.

belajar. Agar peserta didik dapat belajar dengan baik, 
Pedagogik Jurnal Pendidikan, Maret 2014, Volume 9 Nomor 1, (9-38)

usahakan menggunakan pelajaran itu sesuai dengan hobi dan bakatnya.

2. Minat

Minat adalah kecendrungan yang tetap untuk memperhatikan dan mengenang beberapa kegiatan. Minat besar pengaruhnya terhadap belajar, karena bila bahan pelajaran yang dipelajari tidak sesuai dengan minat peserta didik, maka ia tidak akan belajar dengan sebaikbaiknya, Karen tidak ada tarik baginya.

3. Bakat

Bakat adalah kemampuan untuk belajar. Kemampuan itu baru kan terealisasi menjadi kecakapan yang nyata sesudah belajar atau berlatih.

4. Motif

Dalam proses belajar haruslah diperhatikan apa yang dapat mendorong peserta didik dapat belajar dengan baik atau padanya mempunyai motif untuk berpikir dan memusatkan perhatian, merencanakan dan melaksanakan kegiatan yang berhubungan dengan belajar. Motif-motif diatas dapat juga ditanamkan kepada diri peserta didik dengan memberikan pelatihanpelatihan atau kebiasaan yang dipengaruhi oleh lingkungannya.

b. Faktor eksternal adalah faktor yang ada di luar individu.
1. Keluarga

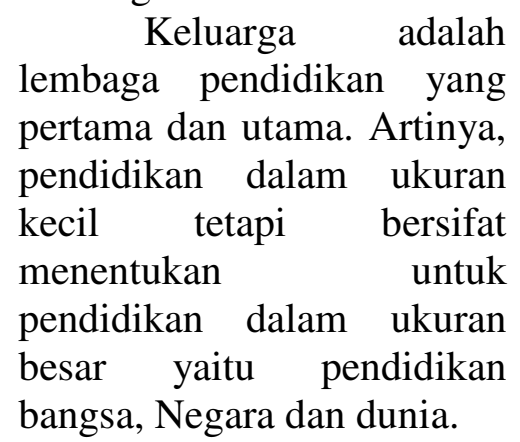

2. Sekolah

Sekolah adalah lembaga pendidikan yang resmi dan disinilah sebagian besar waktu peserta didik dihabiskan untuk mengenyam pendidikan dan pengajaran. Di sekolah peserta didik diajarkan berbagai ilmu pendidikan dan keterampilan yang berguana untuk kehidupannya dimasyarakat.

3. Masyarakat

Masyarakat juga merupakan faktor yang menentukan keberhasilan peserta didik dalam mengenyam pendidikan. Apabila lingkungan sekolah dan lingkungan dimana ia tinggal baik maka, secara sendirinya juga akan berpengaruh pada kepribadian peserta didik menjadi baik. Sebaliknya, apabila lingkungan tinggalnya tidak baik juga akan berdampak pada prilaku dan kepribadian peserta didik itu sendiri. 


\section{METODOLOGI PENELITIAN}

\section{A. Latar Penelitian}

Pendekatan penelitian kualitatif bertujuan mengungkapkan data yang ada dilapangan dengan cara menguraikan dan menginterpretasikan sesuatu seperti apa yang ada dilapangan dan menghubungkan sebab akibat terhadap sesuatu yang terjadi saat penelitian. Tahapan penelitian yang dilakukan di sekolah ini dimulai dengan melakukan observasi awal dan survey, teryata ditemukan permasalahan terkait implementasi pendidikan karakter yang menarik untuk diteliti. Setelah mengajukan ijin meneliti kepada pihak terkait, dan direspon dengan baik maka akan dilanjutkan ke tahapan selanjutnya yaitu pengambilan data dan analisis data hingga diperoleh kesimpulan sebagai hasil akhir penelitian.

\section{B. Metode dan Prosedur Penelitian}

Metode yang digunakan adalah penelitian kualitatif yaitu penelitian tentang data yang dikumpulkan dan dinyatakan dalam bentuk kata-kata dan gambar (wati, 2011). Kata-kata disusun dalam kalimat misalnya, kalimat hasil wawancara antara peneliti dan informan. Penelitian kualitatif bertolak pada filsafat konstruktivisme yang bersamsumsi bahwa ini bersimensi jamak, interaktif dan suatu pertukaran pengalaman sosial yang diinterprestasikan oleh individuindividu. Penelitian kualitatif ditujukan untuk memahami fenomena-fenomena dari sudut perspektif partisipan. Partisipan adalah orang-orang yang diajak berwawancara, di observasi, memberikan data, pendapat, pemikiran, dan persepsinya.

Penelitian ini menggunakan pendekatan kualitatif, yaitu berusaha mendapatkan informasi yang selengkap mungkin mengenai implementasi pendidikan berkarakter di MIS Hidayatul Insan. Informasi yang didapat melalui wawancara dan observasi terhadap informan (kepala sekolah dan guru). Teknik kualitatif digunakan dalam penelitian ini karena pendekatan ini memahami realitas rasional sebagai realitas subyektif khususnya warga sekolah. Proses observasi dan wawancara mendalam bersifat sangat utama dalam pengumpulan data.

Jenis penelitian ini merupakan studi kasus "karena pendekatan ini berusaha menemukan makna, menyelidiki proses, memperoleh pengertian dan pemahaman yang mendalam dari individu, kelompok, atau situasi tertentu, Emzir (2011:20)". Penelitian studi kasus berbeda dari penelitian-penelitian kualitatif lainnya. Karena yang diamati terfokus pada satu "unit tunggal", atau beberapa di suatu sistem terbatas. Untuk memulai sebuah studi kasus, peneliti mengidentifikasi masalah atau pertanyaan yang akan diteliti dan mengembangkan suatu rasional untuk mengapa sebuah studi kasus merupakan metode yang sesuai untuk digunakan dalam studi tersebut.

\section{Data dan Sumber Data}

Data dalam penelitian ini diperoleh melalui subyek penelitian. Data yang dikumpulkan berupa katakata, gambar, dan bukan angka-angka. Hal ini disebabkan oleh adanya penerapan metode kualitatif. Adapun sumber data dalam penelitian ini didapatkan melalui wawancara terhadap kepala sekolah, guru, peserta didik dan lingkungan sekitar yang masih ada hubungannya dengan sekolah. 


\section{Teknik dan Prosedur Pengumpulan Data}

Sesuai dengan bentuk pendekatan penelitian kualitatif dan sumber data yang digunakan, maka teknik pengumpulan data yang digunakan adalah dengan wawancara, observasi, dan dokumentasi. Hal ini senada dengan yang diungkapkan oleh (Bungin,2007) ada tiga cara yang digunakan dalam pengumpulan data kualitatif yaitu:

1. Wawancara

Wawancara dilakukan dengan dua cara yaitu, wawancara terstruktur dan wawancara tidak terstruktur. Wawancara terstruktur adalah pertanyaan-pertanyaannya sudah disiapkan oleh penulis sesuai dengan permasalahan yang akan diteliti. Sedangkan wawancara tidak terstruktur adalah wawancara dilakukan apabila adanya jawaban yang berkembang diluar pertanyaanpertanyaan yang telah disiapkan namun tidak terlepas dari permasalahan penelitian. Dalam penelitian ini, wawancara dipergunakan untuk mengadakan komunikasi dengan pihak-pihak terkait atau objek penelitian, antara lain kepala sekolah, guru kelas, dan warga sekolah lainnya. Alat yang digunakan dalam wawancara adalah buku catatan, dan kamera.

2. Observasi

Observasi adalah kemampuan seseorang menggunakan pengamatannya melalui hasil kerja pancaindra mata serta dibantu dengan pancaindra lainnya. Dalam penelitian ini teknik observasi digunakan untuk memperkuat data. Sedangkan observasi ini sekaligus untuk mengkonfirmasi data yang telah terkumpul melalui wawancara dengan kenyataan yang sebenarnya. Observasi ini digunakan untuk langsung mengamati prilaku peserta didik ketika dalam proses pembelajaran IPA didalam kelas.

\section{Dokumentasi}

Dokumentasi adalah metode yang digunakan untuk menelusuri data historis. Dengan demikian analisis dokumen dilakukan untuk mengumpulkan data yang bersumber dari arsip dan dokumen, baik yang berada di sekolah maupun yang berada di luar sekolah, yang ada hubungannya dengan penelitian tersebut.

\section{E. Instrumen Penelitian}

Instrument yang digunakan dalam penelitian ini adalah instrument yang langsung digunakan untuk menggali data/informasi,peneliti menggunakan angket, sedangkan sebagai pendukung peneliti dalam melakukan penelitian dibantu dengan data-data dokumentasi dan wawancara.

Menurut Sahlan dan Prastyo (2012:178) indikator keberhasilan pendidikan karakter dengan kehidupan siswa dapat dilihat dalam tabel 1 berikut ini: 


\section{Tabel 1}

\section{Indikator keberhasilan pendidikan karakter}

\begin{tabular}{|c|c|c|}
\hline Nilai & Indikator sekolah & Indikator kelas \\
\hline Religius & $\begin{array}{l}\text { 1. Merayakan hari-hari besar keagamaan } \\
\text { 2. Memiliki fasilitas yang dapat digunakan } \\
\text { untuk beribadah } \\
\text { 3. Memberikan kesempatan kepada semua } \\
\text { peserta didik untuk melaksanakan ibadah }\end{array}$ & $\begin{array}{l}\text { 1. Berdo'a sebelum dan sesudah pelajaran } \\
\text { 2. Memberikan kesempatan kepada semua } \\
\text { peserta didik untuk melaksanakan ibadah }\end{array}$ \\
\hline Jujur & $\begin{array}{l}\text { 1. Menyediakan tempat temuan barang hilang } \\
\text { 2. Transparasi laporan keuangan dan penilaian } \\
\text { sekolah secara berkal } \\
\text { 3. Menyediakan kantin kejujuran } \\
\text { 4. Menyediakan kotak saran dan pengaduan } \\
\text { 5. Larangan membawa failitas komunikasi } \\
\text { pada saat ulangan atau ujian }\end{array}$ & $\begin{array}{l}\text { 1. Menyediakan fasilitas untuk temuan } \\
\text { barang hilang } \\
\text { 2. Transparasi laporan keuangan dan } \\
\text { penilaian kelas secara berkala } \\
\text { 3. Larangan menyontek }\end{array}$ \\
\hline Toleransi & $\begin{array}{l}\text { 1. Menghargai dan memberikan pelakuan yang } \\
\text { sama terhadap seluruh warga sekolah tanpa } \\
\text { membedakan suku, agama, ras, status sosial, } \\
\text { status ekonomi, dan kemampuan khas }\end{array}$ & $\begin{array}{l}\text { 1. Memberikan pelayanan yang sama } \\
\text { terhadap seluruh warga kelas tanpa } \\
\text { membedakan suku, ras, golongan, status } \\
\text { sosial, dan status ekonomi } \\
\text { 2. Memberikan pelayanan terhadap anak } \\
\text { berkebutuhan khusus } \\
\text { 3. Bekerja dalam kelomppok yang berbeda }\end{array}$ \\
\hline Disiplin & $\begin{array}{l}\text { 1. Memiliki catatan kehadiran } \\
\text { 2. Memberikan penghargaan kepada warga } \\
\text { sekolah yang disiplin } \\
\text { 3. Memiliki tata tertib sekolah } \\
\text { 4. Membiasakan warga sekolah untuk } \\
\text { berdisiplin } \\
\text { 5. Menegakkan aturan dengan memberikan } \\
\text { sanksi secara adil begi pelanggar tata tertib } \\
\text { sekolah }\end{array}$ & $\begin{array}{l}\text { 1. Membiasakan hadir tepat waktu } \\
\text { 2. Membiasakan memauhi aturan }\end{array}$ \\
\hline Kerja keras & $\begin{array}{l}\text { 1. Menciptakan suasana kompetisi yang sehat } \\
\text { 2. Menciptakan suasana sekolah yang } \\
\text { menantang dan memacu untuk bekerja keras } \\
\text { 3. Memiliki pajangan tentang slogan atau moto } \\
\text { tentang kerja }\end{array}$ & $\begin{array}{l}\text { 1. Suasana kompetisi } \\
\text { 2. Menciptakan kondisi etos kerja } \\
\text { 3. Menciptakan suasan belajar yang } \\
\text { memacu daya tahan kerja } \\
\text { 4. Memiliki slogan atau moto tentang giat } \\
\text { bekerja dan belajar }\end{array}$ \\
\hline Kreatif & $\begin{array}{l}\text { Menciptakan situasi yang menumbuhkan } \\
\text { daya berpikir dan bertindak kreatif }\end{array}$ & $\begin{array}{l}\text { 1. Menciptakan situasi belajar yang bisa } \\
\text { menumbuhkan daya piker dan bertindak } \\
\text { kreatif } \\
\text { 2. Pemberian tugas yang menantang } \\
\text { memunculkan karya-karyabaru baik yang } \\
\text { autentik maupun modifikasi }\end{array}$ \\
\hline Mandiri & $\begin{array}{l}\text { Menciptakan situasi sekolah yang } \\
\text { membangun kemandirian peserta didik }\end{array}$ & $\begin{array}{l}\text { Menciptakan suasana kelas yang } \\
\text { memberikan kesempatan kepada peserta } \\
\text { didik untuk bekerja mandiri }\end{array}$ \\
\hline Demokratis & $\begin{array}{l}\text { 1. Melibatkan kepala sekolah dalam setiap } \\
\text { pengambilan keputusan }\end{array}$ & $\begin{array}{l}\text { 1. Mengambil keputusan kelas secara } \\
\text { bersama melalui musyawarah dan }\end{array}$ \\
\hline
\end{tabular}




\begin{tabular}{|c|c|c|}
\hline & $\begin{array}{l}\text { 2. Menciptakan suasana } \\
\text { menerima perbedaan }\end{array}$ & 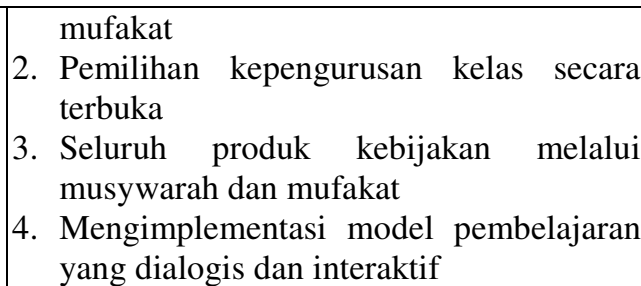 \\
\hline & $\begin{array}{l}\text { 1. Menyediakan media } \begin{array}{l}\text { komunikasi atau } \\
\text { informasi }\end{array} \\
\text { 2. Memfasilitasi warga sekolah untuk } \\
\text { bereksplotasi dalam pendidikan, ilmu } \\
\text { pengetahuan, teknologi, dan budaya }\end{array}$ & $\begin{array}{l}\text { 1. Menciptakan suasana kelas yang } \\
\text { mengandung rasa ingin tahu } \\
\text { 2. Ekslporasi lingkungan secara terprogram } \\
\text { 3. Tersedia media komunikasi atau } \\
\text { informasi }\end{array}$ \\
\hline & $\begin{array}{l}\text { 1. Melakukan upacara rutin di sekolah } \\
\text { 2. Melakukan upacara hari-hari besar nasional } \\
\text { 3. Menyelenggarakan peringatan hari } \\
\text { kepahlawanan nasional } \\
\text { 4. Melakukan kunjungan ke tempat bersejarah } \\
\text { 5. Mengikuti lomba pada hari besar nasional }\end{array}$ & $\begin{array}{l}\text { 1. Bekerjasama dengan teman sekelas yang } \\
\text { berbeda suku, ras, etnis, maupun budaya } \\
\text { 2. Mediskusikan hari-hari besar nasional }\end{array}$ \\
\hline & $\begin{array}{l}\text { 1. Menggunakan produk dalam negeri } \\
\text { 2. Menggunakan bahasa Indonesia yang baik } \\
\text { dan benar } \\
\text { 3. Menyediakan informasi tentang kekayaan } \\
\text { alam dan budaya Indonesia }\end{array}$ & $\begin{array}{l}\text { 1. Memajangkan: foto presiden dan wakil } \\
\text { presiden, bendera Negara, lambing } \\
\text { Negara, peta Indonesia, dan gambar } \\
\text { kehidupan masyarakat Indonesia } \\
\text { 2. Menggunakan produk buatan dalam } \\
\text { negeri }\end{array}$ \\
\hline Bersahabat/ & $\begin{array}{l}\text { 1. Suasana sekolah yang memudahkan } \\
\text { terjadinya interaksi antar warga sekolah } \\
\text { 2. Berkomunikasi dengan bahasa yang santun } \\
\text { 3. Saling menghargai dan menjaga kehormatan } \\
\text { 4. Pergaulan dengan cinta kasih dan rela } \\
\text { berkorban }\end{array}$ & $\begin{array}{l}\text { 1. Pengaturan kelas yang memudahkan } \\
\text { terjadinya interaksi peserta didik } \\
\text { 2. Pembelajaran yang dialogis } \\
\text { 3. Guru mendengarkan keluhan peserta } \\
\text { didik } \\
\text { 4. Dalam berkomunikasi guru tidak } \\
\text { menjaga jarak dengan peserta didik }\end{array}$ \\
\hline Cinta damai & $\begin{array}{l}\text { 1. Menciptakan suasana sekolah dan bekerja } \\
\text { yang nyaman, tentram, dan harmonis } \\
\text { 2. Membiasakan prilaku warga sekolah yang } \\
\text { anti kekerasan } \\
\text { 3. Membiasakan prilaku warga sekolah yang } \\
\text { bias gender } \\
\text { 4. Perilaku seluruh warga sekolah yang penuh } \\
\text { kasih saying }\end{array}$ & $\begin{array}{l}\text { 1. Menciptakan suasana kelas yang damai } \\
\text { 2. Membiasakan prilaku warga sekolah } \\
\text { yang anti kekerasan } \\
\text { 3. Kekerabatan di kelas yang penuh kasih } \\
\text { saying }\end{array}$ \\
\hline $\begin{array}{l}\mathrm{Ge} \\
\mathrm{me}\end{array}$ & $\begin{array}{l}\text { 1. Program wajib membaca } \\
\text { 2. Frekuensi kunjungan ke perpustakaan } \\
\text { 3. Menyediakan fasilitas dan suasana } \\
\text { menyebangkan untuk membaca }\end{array}$ & $\begin{array}{l}\text { 1. Daftar buku atau tulisan yang dibaca } \\
\text { peserta didik } \\
\text { 2. Frekuensi kunjungan ke perpustakaan } \\
\text { 3. Saling tukar bacaan } \\
\text { 4. Pembelajaran yang memotivasi peserta } \\
\text { didik menggunakan referensi }\end{array}$ \\
\hline $\begin{array}{l}\text { Peduli } \\
\text { lingkungans }\end{array}$ & $\begin{array}{l}\text { 1. Pembiasaan memelihara kebersihan dan } \\
\text { kelestarian lingkungan sekolah } \\
\text { 2. Tersedia tempat pembuangansampah dan } \\
\text { tempat cuci tangan } \\
\text { 3. Menyediakan kamar mandi dan air bersih } \\
\text { Pembiasaan hemat energi } \\
\text { 4. Membuat biopori di area sekolah }\end{array}$ & $\begin{array}{l}\text { 1. Memelihara lingkungan kelas } \\
\text { 2. Tersedia tempat pembuangan sampah di } \\
\text { dalam kelas } \\
\text { 3. Pembiasaan hemat energi }\end{array}$ \\
\hline
\end{tabular}




\begin{tabular}{|c|c|c|}
\hline & $\begin{array}{l}\text { 5. Membangun saluran limbah air dengan baik } \\
\text { 6. Melakukan pembiasaan memisahkan } \\
\text { sampah organik dan non organik } \\
\text { 7. Penugasan pembuatan kompos dari sampah } \\
\text { organic } \\
\text { 8. Menyediakan peralatan kebersihan } \\
\text { 9. Membuat tandon penyimpanan air }\end{array}$ & \\
\hline Peduli social & $\begin{array}{l}\text { 1. Memfasilitasi kegiatan bersifat sosial } \\
\text { 2. Melakukan aksi sosial } \\
\text { 3. Menyediakan fasilitas untuk menyumbang }\end{array}$ & $\begin{array}{l}\text { 1. Berempati sesama teman kelas } \\
\text { 2. Melakukan aksi social } \\
\text { 3. Membangun kerukunan warga kelas }\end{array}$ \\
\hline $\begin{array}{l}\text { Tanggung } \\
\text { jawab }\end{array}$ & $\begin{array}{l}\text { 1. Membuat laporan setiap kegiatan yang } \\
\text { dilakukan dalam bentuk lisan meupun } \\
\text { tertulis } \\
\text { 2. Melakukan tugas tanpa disuruh } \\
\text { 3. Menunjukkan prakarsa untuk mengatasi } \\
\text { masalah dalam lingkup terdekat } \\
\text { 4. Menghindarkan kecurangan dalam } \\
\text { pelaksanaan tugas }\end{array}$ & $\begin{array}{l}\text { 1. Pelaksanaan tugas piket secara teratur } \\
\text { 2. Peran serta aktif dalam kegiatan sekolah } \\
\text { 3. Mengajukan usul pemecahan masalah }\end{array}$ \\
\hline
\end{tabular}

Dari indikator-indikator di atas dapat dipahami bahwa, apabila semua indikator dapat dilaksanakan maka tentunya karakter peserta didik pasti akan dapat mengubah bangsa ini menjadi lebih baik lagi. Akan tetapi, semua ini perlu kerja keras dan dukungan dari semua pihak untuk mewujudkannya.

\section{F. Prosedur Analisis Data}

"Analisis data adalah proses
mencari dan menyusun secara sistematis data yang diperoleh dari hasil wawancara, catatan lapangan, dan bahan-bahan lain, sehingga dapat mudah dipahami, dan temuannya dapat dinformasikan kepada orang lain" (Sugiyono, 2010:88). Analisis data dilakukan dengan mengorganisasikan data, menjabarkannya ke dalam unitunit, melakukan sintesa, menyusun ke dalam pola, memilih mana yang penting dan yang akan dipelajari, dan membuat kesimpulan yang dapat diceritakan kepada orang lain.
Analisis data kualitatif adalah bersifat induktif, yaitu suatu analisis berdasarkan data yang diperoleh, selanjutnya dikembangkan menjadi hipotesis. Berdasarkan hipotesis yang dirumuskan data tersebut, selanjutnya dicarikan data lagi secara berulangulang sehingga selanjutnya dapat disimpulkan apakah hipotesis tersebut dapat diterima atau ditolak berdasarkan data yang terkumpul. Proses analisis data dimulai sejak pengumpulan data dan dilakukan secara intensif.

1. Reduksi data

Mereduksi data berarti merangkum, melilih hal-hal yang pokok, memfokuskan pada hal-hal yang penting, dicari tema dan polanya. Dengan demikian data yang telah direduksi akan memberikan gambaran yang lebih jelas, dan mempermudah peneliti untuk melakukan pengumpulan data selanjutnya, dan mencarinya bila diperlukan. Redukdi data merupakan penyederhanaan yang 
Pedagogik Jurnal Pendidikan, Maret 2014, Volume 9 Nomor 1, (9-38)

muncul dari catatan lapangan sebagai upaya untuk mengorganisasikan data dan memudahkan penarikan kesimpulan.

2. Penyajian data

Penyajian data yaitu data yang dihasilkan melalui proses reduksi data akan langsung disajikan sebagai sekumpulan informasi tersusun yang memberikan kemungkinan adanya penarikan dan pengambilan tindakan.

3. Pengambilan kesimpulan dan verifikasi

Sejak pengumpulan data peneliti harus membuat simpulan-simpulan sementara. Dalam tahap akhir, simpulan tersebut harus dicek kembali (diverifikasi) pada catatan yang telah dibuat oleh peneliti selanjutnya kearah simpulan yang mantap. Mengambil kesimpulan merupakan proses penarikan intisari dari data-data yang terkumpul dalam bentuk pernyataan kalimat yang tepat dan memiliki data yang jelas. Kesimpulan adalah intisari temuan penelitian yang menggambarkan pendapat-pendapat terakhir yang berdasarkan pada uaraian-uraian sebelumnya atau keputusan yang diperoleh berdasarkan metode berfikir induktif (Wati, 2011).

Verifikasi yaitu proses mencari benda-benda, mencatat keteraturan, pola-pola penjelasan. Kesimpulan yang diverifikasi selama penelitian berlangsung untuk mencari kesimpulan akhir. Proses verifikasi dilakukan sejak peneliti melakukan pengecekan terhadap data-data yang di reduksi secara bertahap penyajian data dan kesimpulan sehingga benar-benar terseleksi data tersebut.

Kesimpulan juga diverifikasi selama penelitian berlangsung. Proses penyimpulan biasanya dilakukan secara bertahap, misalnya tahap pertama diberikan suatu kesimpulan, tahap kedua juga dilakukan kesimpulan, demikian juga dengan tahap ketiga dan akhirnya secara keseluruhan disimpulkan dengan menggunakan logika.

Reduksi data, penyajian data, dan penarikan kesimpulan atau verifikasi merupakan tiga alur kegiatan analisis data sebagai proses siklus yang terintegrasi. Tahapan analisis data kualitatif di atas dapat dilihat pada gambar 1 berikut ini (Sugiyono, 2011).

\section{G. Pemeriksaan Keabsahan Data}

Pemeriksaan keabsahan data sangat diperlukan dalam penelitian kualitatif demi keshahihan dan keandalan serta tingkat kepercayaan data yang telah terkumpul.

\section{Kredibilitas}

Proses dan hasil penelitian dapat diterima atau dipercaya. Lincoln dan Guba (1985) menyatakan bahwa untuk memperoleh data yang valid dapat ditempuh melalui:

a. lama penelitian, memperpanjang masa pengamatan memungkinkan peningkatan derajat kepercayaan data yang dikumpulkan, bisa mempelajari kebudayaan dan dapat menguji informasi dari responden.

b. observasi yang detail, pengamatan yang terus menerus untuk menemukan ciri-ciri dan 
unsur-unsur dalam situasi yang sangat relevan dengan persoalan yang sedang diteliti.

c. triangulasi, pemeriksaan keabsahan data yang memanfaatkan sesuatu yang lain diluar data untuk keperluan pengecekan atau sebagai pembanding terhadap data tersebut.

d. Peer debriefing, membicarakan dengan orang lain dengan mengekspos hasil sementara atau hasil akhir yang diperoleh dalam bentuk diskusi analitik dengan rekan sejawat.

e. analisis kasus negatif, dilakukan dengan jalan mengumpulkan contoh dan kasus yang tidak sesuai dengan pola dan kecenderungan informasi yang telah dikumpulkan dan digunakan sebagai bahan pembanding

f. member check, dengan menguji kemungkinan dugaan-dugaan yang berbeda dan mengembangkan pengujian untuk mengecek analisis.

\section{Transferabilitas}

Hasil penelitian ini dapat diterapkan pada situasi yang lain. Transferabilitas atau keteralihan dicapai dengan cara uraian rinci. Untuk kepentingan ini peneliti berusaha melaporkan hasil penelitiannya secara rinci.

\section{Dependabilitas}

Hasil penelitian mengacu pada tingkat konsistensi peneliti dalam mengumpulkan data, membentuk, dan menggunakan konsep-konsep ketika membuat interpretasi untuk menarik kesimpulan. Dependabilitas atau kebergantungan dilakukan untuk menanggulangi kesalahankesalahan dalam konseptualisasi rencana penelitian, pengumpulan data, interpretasi temuan, dan pelaporan hasil penelitian. Untuk itu diperlukan dependent auditor dalam hal ini adalah para pembimbing.

\section{Konfirmabilitas}

Hasil penelitian dapat dibuktikan kebenarannya dimana hasil penelitian sesuai dengan data yang dikumpulkan dan dicantumkan dalam laporan lapangan. Hal ini dilakukan dengan membicarakan hasil penelitian dengan orang yang tidak ikut dan tidak berkepentingan dalam penelitian dengan tujuan agar hasil dapat lebih objektif. Perbedaannya dengan dependabilitas adalah pada konfirmabilitas pengauditan digunakan untuk menilai hasil (product) penelitian, sedangkan pengauditan pada dependabilitas digunakan untuk menilai proses yang dilalui peneliti dilapangan.

\section{HASIL PENELITIAN DAN}

\section{PEMBAHASAN}

\section{A. Temuan Penelitian}

\section{Implementasi} Karakter

Setelah melakukan observasi di MIS Hidayatul Insan Palangka Rayamaka temuan yang peneliti temukan adalah data-data yang dapat menunjang kelengkapan data penelitian yaitu berupa data peserta didik, guru, sarana dan prasaran serta penerapan pendidikan karakter di sekolah ini. Dengan demikian dapat diuraikan sebagai berikut. 
Pada dasarnya peserta didik tidak mengerti dengan istilah karakter. bagi mereka yang terpenting adalah peserta didik mengikuti peraturan yang ada di sekolah, mendapatkan pembelajaran di dalam kelas, kemudian tugas yang mereka kerjakan mendapatkan nilai sesuai dengan yang mereka inginkan. Masalah metode, cara, ataupun pendekatan karakter yang guru gunakan itu semua bukan tanggung jawab dari peserta didik. Maka dari itu guru dituntut untuk selalu memberikan panutan yang terbaik dan dapat menyediakan apa yang mereka butuhkan seperti, memberikan pelayanan dan pengajaran yang sesuai dengan kebutuhan mereka dan juga dapat menyediakan fasilitas, sarana dan prasarana yang bisa menunjang prestasi mereka.

Bagaimanapun peran orang tua dominan terhadap pembentukan karakter peserta didik. Namun, tampaknya trends orang tua sekarang kurang memperhatikan aspek-aspek ini dan lebih banyak memperhatikan bagaimana peserta didik dapat bersaing dengan yang lain. Hampir semua mata pelajaran di tingkat SD dapat disisipi oleh pendidikan karakter. Demikian halnya dengan pembelajaran IPA. IPA yang sarat akan nilai religius, nilai saintifik, dan nilai sosial sebaiknya perlu digali dan dikemas dalam pembelajaran.

Untuk dapat mengimplikasikan nilai karakter perlu menciptakan dan meningkatkan karakter peserta didik. Selain itu, pembelajaran IPA di SD akan lebih bermakna jika guru dapat mengembangkan pembelajaran pada ranah inkuiri ilmiah dengan pendekatan kontekstual. Jika materi pelajaran dikaitkan dengan situasi nyata dunia sekitar peserta didik, maka pembelajaran akan lebih bermakna.

Berkenaan dengan pendidikan karakter, yaitu dari hasil wawancara dengan kepala sekolah di MIS Hidayatul Insan Palangka Raya menyatakan:

Setiap warga Sekolah MIS Hidayatul Insan Palangka Raya diharuskan dapat memberikan keteladanan, perbuatan yang baik, saling menghormati, menghargai yang di awali dari diri sendiri serta dapat diterapkan dalam kehidupan sehari-hari dan lingkungan disekitarnya. (TM. 14-02-2013)

Kemudian pada saat kesempatan lain peneliti melakukan wawancara dengan guru kelas $\mathrm{V}$ tentang bagaimana penerapan pendidikan karakter terhadap pelajaran IPA di sekolah ini beliau menyatakan:

Pada dasarnya pendidikan karakter sudah diajarkan sejak dahulu akan tetapi, biasanya hanya pada mata pelajaran tertentu walaupun secara tidak sadar juga sudah pada semua mata pelajaran dan sudah dipraktikkan seperti, mengucapkan salam, mencium tangan guru ketika bersalaman dan lain-lain. Khusus untuk pelajaran IPA karakter yang diharapkan adalah ketekunan, ketelitian, menemukan, tanggung jawab dan lain-lain. (LS. 16-02-2013)

Dari hasil wawancara di atas dapat disimpulkan bahwa kepala sekolah dan guru ketika mengajar akan berusaha selalu memberikan suri tauladan yang 
baik dan juga memberikan contoh karakter yang baik pula agar bisa diingat dan diterapkan oleh peserta didik dalam kehidupan sehari-hari.

\section{Kondisi dari Peserta Didik}

Penerapan pendidikan karakter merupakan layanan bimbingan dan tanggung jawab guru terhadap peserta didik untuk selalu memberikan layanan yang terbaik bagi peserta didik. Guru dituntut untuk selalu memahami kondisi dan karakter masing-masing peserta didik apakah sedang semangat belajar atau malas belajar, tentunya hal ini tidak akan terjadi pada semua peserta didik tetapi, pada praktiknya guru harus bisa, selain mengusai materi dan penggunaan media juga mampu mengkondisikan apapun yang terjadi di dalam kelas ketika proses pembelajaran.

Di samping itu komponen lain yang guru harus miliki adalah bersikap sabar dan suka menolong, kedua karakter inilah yang tidak semua guru miliki ketika mengajar. Padahal seharusnya kedua sikap ini harus dimiliki oleh semua guru agar nantinya peserta didik akan lebih berani untuk bertanya ketika ia kurang memahami apa yang disampaikan guru dan juga guru akan lebih dekat dengan peserta didik, dengan demikian guru akan lebih mudah memahami kesulitankesulitan yang dialami peserta didik.

Dengan demikian, agar penerapan pendidikan karakter bisa berjalan dengan baik dibutuhkan kerja sama yang baik antara sekolah, keluarga dan lingkungan di sekitar sekolah. Sehingga semua pihak dapat sama-sama saling memantau apa yang sedang dilakukan oleh peserta didik dan juga jika ada perubahan sikap dari peserta didik.

Berkenaan dengan kondisi dari peserta didik yang mengikuti pembelajaran IPA, serta hasil wawancara dari salah satu peserta didik mengatakan:

Ketika mengikuti pembelajaran IPA guru selalu menjelaskan materi pelajaran dengan mudah dipahami dan dapat dimengerti sehingga, kami akan bisa mangerjakan soal dengan baik (RA. 16-02-2013).

Kemudian melakukan wawancara kembali dengan peserta didik lain dengan pertanyaan apakah anda suka dengan guru yang suka menolong dan sabar ketika sedang menjelaskan materi di depan kelas?

Suka! Karena jadinya saya nanti tidak takut untuk bertanya ketika saya tidak mengerti dengan apa yang telah disampaikan oleh guru di depan kelas (IS. 17-022013).

Dari hasil wawancara di atas dapat disimpulkan bahwa pada dasarnya semua peserta didik ingin diperhatikan dengan penanganan yang lembut dan halus sehingga tidak akan mempengaruhi psikologinya.

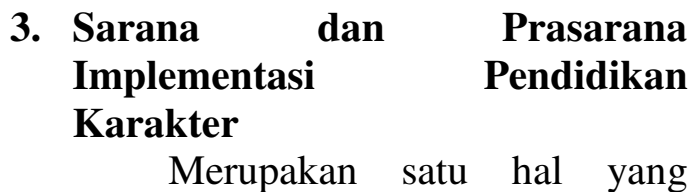
mendasar untuk membantu dan memperlancar pembelajaran yang ada di sekolah agar pelayanan proses belajar mengajar dapat 
berjalan dengan baik. Berdasarkan hasil wawancara dengan kepala sekolah tentang apa saja sarana dan prasarana yang dimiliki sekolah untuk menunjang pembelajaran di dalam kelas beliau menyatakan bahwa:

Dalam setiap pembelajaran didalam kelas guru diharapkan ketika menjelaskan materi disesuaikan dengan silabus, RPP, ruangan kelas, dan bahkan menggunakan media pembelajaran dengan harapan peserta didik akan lebih cepat mengerti materi yang kita sampaikan (TM. 14-02-2013)

Kemudian melakukan wawancara kembali dengan salah satu peserta didik tentang apakah anda suka ketika guru dalam menjelaskan materi pembelajaran menggunakan alat atau media pembelajaran ia menyatakan bahwa:

Saya sangat suka ketika guru menggunakan alat atau media pembelajaran ketika mengajar karena saya dan teman-teman akan lebih mudah memahami apa yang telah disampaikan oleh guru di depan kelas (NK. 20-022013)

Dari hasil wawancara di atas dapat disimpulkan bahwa antara guru dan peserta didik sama-sama setuju apabila dalam proses pembelajaran guru menggunakan media pembelajaran.

\section{Kondisi Lingkungan Sekolah} Lingkungan sangat berpengaruh terhadap perubahan tingkah laku peserta didik, karena di lingkungan watak dan keperibadian peserta didik akan terbentuk. Oleh karena itu sekolah dan orang tua harus dapat bekerja sama dalam mengawasi setiap perubahan tingkah laku yang terjadi pada peserta didik. Ketika peserta didik di sekolah itu menjadi tanggung jawab dari semua guru akan tetapi ketika di rumah peserta didik menjadi tanggung jawab dari orang tua itu sendiri.

Dengan demikian pendidikan karakter diharapkan mampu menjawab semua persoalan dalam pembentukan karakter para peserta didik, mengingat dewasa ini karakter peserta didik sudah sangat jauh mengalami kemunduran sehingga perlu adanya perubahan yang besar untuk mewujudkan semua itu di perlukan kerja keras dari semua pihak agar bisa merubah watak dan kepribadian peserta didik menjadi lebih baik.

\section{B. Pembahasan}

\section{Implementasi pendidikan karakter di MIS Hidayatul Insan Palangka Raya}

Pendidikan karakter penting untuk diimplikasikan mulai sekolah dasar karena melalui pendidikan ini, karakter seorang peserta didik dapat terbentuk, tentunya dengan melibatkan lingkungannya. Saat ini, banyak orang beranggapan karakter peserta didik semakin tipis dan mengalami perubahan. Hal ini dipengaruhi oleh banyak faktor, seperti masuknya budaya asing yang tidak sesuai dengan kepribadian bangsa, juga tak luput dari sistem pendidikan yang kurang mengintegrasikan nilai dalam setiap ranah pembelajaran. Peserta didik 
menjadi lemah karakternya karena karakter-karakter yang ingin ditanamkan sebatas untuk dihafal dan bukan untuk diterapkan dalam kehidupan sehari-hari.

Seperti yang telah di ungkapkan sebelumnya bahwa peran orang tua di jaman modern ini sering gagal dalam membentuk karakter anak-anaknya, sehingga pendidikan karakter di sekolah adalah solusi yang tepat, apalagi kalau peserta didik tidak mendapatkan pendidikan karakter di rumahnya. Waktu peserta didik banyak dihabiskan di sekolah, dan apa yang terekam dalam memori peserta didik mengenai pengalaman di sekolah akan mempengaruhi kepribadian peserta didik ketika dewasa.

Sekolah adalah tempat yang strategis untuk pendidikan karakter, karena peserta didik dari semua lapisan akan mengenyam pendidikan di sekolah, sehingga apa yang didapatkannya di sekolah akan mempengaruhi pembentukan karekternya. Sebuah pendidikan yang berhasil adalah yang dapat membentuk manusia-manusia berkarakter yang sangat diperlukan dalam mewujudkan sebuah Negara kebangsaan yang terhormat.

Berkenaan dengan definisi diatas dan hasil wawancara dengan kepala sekolah tentang bagaimana tanggapan orang tua terhadap pendidikan karakter, kepala sekolah menyatakan.

Respon orang tua terhadap pendidikan karakter sangat bagus, karena sejak pendidikan karakter diterapkan di sekolah ini sikap, tingkah lakunya peserta didik mulai ada perubahan yang biasanya ketika di rumah tidak mengucapkan salam, sudah mulai mau mengucapakan salam. Kemudian di sekolah juga pergaulan sesama teman, dengan guru juga sudah banyak mengalami perubahan mengarah yang lebih baik (TM. 14-02-2013)

Dari hasil wawancara di atas dapat disimpulkan bahwa dengan di terapkannya pendidikan karakter orang tua sangat mendukung dengan program ini, karena bukti perubahan sikap peserta didik sudah mulai dirasakan oleh orang tua.

Hasil yang dicapai dengan diterapkannya pendidikan karakter ini adalah sudah berdampak pada nilai rapot dari peserta didik yang mengalami kenaikan, hal ini sesuai dengan yang dinyatakan oleh guru kelas V bahwa :

Dengan diterapkannya pendidikan karakter di sekolah ini, sudah ada peningkatan hasil belajar peserta didik meskipun tidak signifikan karena, pendidikan karakter ini baru diterapkan mulai semester 1( LS. 16-02-2013)

Untuk menyakinkan pertanyaan saya ini, kemudian saya bertanya kembali dengan salah satu guru kelas $\mathrm{V}$ lainnya dengan pertanyaan yang sama, yaitu bagaimana hasil belajar peserta didik sejak diterapkannya pendidikan karakter menyatakan bahwa:

Hasil belajar peserta didik tergantung dari mereka 
bagaimana peserta didik mengikuti proses pembelajaran di dalam kelas. Ketika peserta didik menyimak dengan baik tentu hasilnya juga baik sebaliknya, kalau mereka kurang memperhatikan tentu hasilnya juga kurang baik.Tetapi ratarata nilai peserta didik sudah mulai menunjukkan peningkatan (SM. 22-02-2013)

Dari hasil wawancara di atas dapat disimpulkan bahwa sejak diterapkannya pendidikan karakter di sekolah ini sikap, tingkah laku, dan hasil belajar peserta didik sudah mulai menunjukkan perubahan walaupun belum signifikan.

Adapun faktor-faktor penghambat dalam penerapan pendidikan karakter adalah karena pendidikan karakter masih baru diterapkan di sekolah ini, sehingga peserta didik butuh waktu untuk beradaptasi dalam mengikuti ketentuan-ketentuan yang berlaku dalam pendidikan karakter.

Berdasarkan wawancara dengan guru kelas $\mathrm{V}$ untuk mengetahui penghambat dan cara mengatasi penerapan pendidikan karakter di MIS Hidayatul Insan Palangka Raya yaitu mangatakan bahwa :

Faktor penghambatnya adalah guru di dalam pendidikan karakter ini hanya sebagai fasilitator saja, sehingga dalam proses pembelajarannya peserta didiklah yang harus berusaha memahami materi yang ada di buku, walaupun tidak menutup kemungkinan para guru juga masih menjelaskan materi di depan kelas. Jadi, kesimpulannya yang rajin semakin rajin dan pintar sebaliknya, yang malas semakin tertinggal dengan temannya. Tetapi, kami selaku guru di sekolah ini berusaha mengatasi masalahmasalah yang terjadi pada peserta didik, dengan selalu memberikan pengarahan dan motivasi kepada semua peserta didik untuk terus belajar dan mencoba dekat dengan semua dengan demikian kami tahu apa yang dibutuhkan oleh peserta didik (LS. 16-02-2013)

\section{Kondisi lingkungan MIS Hidayatul Insan Palangka Raya}

Lingkungan sangat berpengaruh terhadap perubahan tingkah laku peserta didik, hal ini tentunya juga harus didukung oleh semua pihak atau keluarga besar di sekolah tersebut. Apabila didalam lingkungan sekolah peserta didik hidup dengan rukun dan damai tentunya kebiasaan ini akan terbawa dalam kehidupan peserta didik ketika hidup dilingkungan masyarakat. Tentunya untuk mewujudkan semua ini perlu kerja keras dari peserta didik maka dari itu, sekolah selalu mewajibkan semua peserta didik untuk selalu menaati peraturan yang ada dan juga selalu menjaga kebersihan lingkungan sekolah, yaitu dengan membuang sampah pada tempatnya, mencuci tangan, dan tidak boleh mencoret-coret dinding sekolah.

Berdasarkan hasil wawancara dengan peserta didik mengenai kondisi lingkungan sekolah mengatakan bahwa: 
Kondisi lingkungan sekolah kami yang bersih dan nyaman membuat kami senang dan betah dalam mengikuti proses pembelajaran, karena tidak ada sampah yang berserakan di dalam kelas maupun di luar kelas dan tidak menjadi pemandangan yang kurang enak dipandang (WT. 17 -022013)
Berdasarkan hasil wawancara di atas dapat disimpulkan bahwa, dengan kondisi lingkungan yang bersih dan nyaman membuat kami betah di sekolah dan senang dalam mengikuti proses pembelajaran di kelas.

Menurut Sahlan dan Prastyo (2012:178) indikator keberhasilan pendidikan karakter dengan kehidupan siswa dapat dilihat dalam tabel 10 berikut ini:

Tabel 2.

Gambaran Implementasi Pendidikan Karakter Setiap Hari di MIS Hidayatul Insan Palangkaraya.

\begin{tabular}{|c|c|c|}
\hline Waktu & Kegitan & Nilai yang dikembangkan \\
\hline $\begin{array}{r}\text { i sebelum } \\
\text { kegiatan }\end{array}$ & $\begin{array}{l}\text { Guru piket ( } 2 \text { orang) dan guru lain bersiap } \\
\text { menyambut kedatangan peserta didik dan } \\
\text { mengucapkan salam. Peserta didik masuk } \\
\text { sendiri tanpa ditemanani orang tua. }\end{array}$ & Kemandirian, sopan, santun \\
\hline $15-06.30$ & $\begin{array}{l}\text { 1. Sekitar } 15 \text { menit peserta didik dan guru } \\
\text { melakukan kegiatan "sapu bersih-bersih", } \\
\text { yaitu mengumpulkan sampah yang ada } \\
\text { disekolah } \\
\text { 2. melakukan shalat dhuha berjamaah }\end{array}$ & Kebersihan, religius \\
\hline $30-07.00$ & $\begin{array}{l}\text { 1. Hari senin upacara bendera di halaman } \\
\text { sekolah } \\
\text { 2. Hari selasa, rabu, kamis, jum'at: berkumpul } \\
\text { di aula, penekanan nilai-nilai religius sesuai } \\
\text { dengan keyakinannya yang dipimpin guru } \\
\text { agama masing-masing }\end{array}$ & $\begin{array}{l}\text { Kedisiplinan, religius, ke- } \\
\text { Mandirian }\end{array}$ \\
\hline $00-11.30$ & $\begin{array}{l}\text { Kegiatan rutin kelas } \\
\text { 1. Pembukaan } \\
\text { 2. Kegiatan inti } \\
\text { 3. Penutup } \\
\text { 4. Sebelum pulang bersih-bersih kelas (piket } \\
\text { kelas) }\end{array}$ & $\begin{array}{l}\text { Religius, kebersihan,kedi- } \\
\text { Siplinan }\end{array}$ \\
\hline
\end{tabular}


Pedagogik Jurnal Pendidikan, Maret 2014, Volume 9 Nomor 1, (9-38)

Tabel 3.

Beberapa Contoh Pembudayaan Pendidikan Karakter di SDN 1

Panarung Palangkaraya.

\begin{tabular}{|c|c|}
\hline Nilai pendidikan karakter & Bentuk kegiatan \\
\hline Religius & $\begin{array}{l}\text { 1. Merayakan hari-hari besar agama } \\
\text { 2.Memfasilitasi tempat yang dapat digunakan untuk beribadah } \\
\text { 3. Berdo'a sebelum dan sesudah pelajaran } \\
\text { 4. Memberikan kesempatan peserta didik untuk beribadah } \\
\text { 5. mengikuti perlombaan islami }\end{array}$ \\
\hline Jujur & $\begin{array}{l}\text { 1. penyediaan fasilitas tempat temuan hilang } \\
\text { 2.transparasi laporan keuangan dan penilaian sekolah secara berkala } \\
\text { 3. meyediakan kantin kejujuran } \\
\text { 4. menyediakan kotak saran dan pengaduan } \\
\text { 5.larangan membawa fasilitas komunikasi pada saat ulangan atau ujian }\end{array}$ \\
\hline Toleransi & $\begin{array}{l}\text { menghargai dan memberikan perlakuan yang sama terhadap warga } \\
\text { sekolah tanpa membedakan suku, agama, ras, golongan, status sosial, } \\
\text { ekonomi, dan kemampuan. }\end{array}$ \\
\hline Disiplin & $\begin{array}{l}\text { 1. memiliki catatan kehadiran } \\
\text { 2. memberikan penghargaan terhadap warga sekolah yang disiplin } \\
\text { 3. memiliki tata tertib sekolah } \\
\text { 4. membiasakan diri untuk disiplin }\end{array}$ \\
\hline Kerja keras & $\begin{array}{l}\text { 1. menciptakan suasana yang sehat } \\
\text { 2. pantang menyerah, dan daya tahan belajar } \\
\text { 3.memiliki slogan atau motto tentang giat bekerja dan belajar }\end{array}$ \\
\hline
\end{tabular}

Tabel 4

Indikator keberhasilan pendidikan karakter

\begin{tabular}{|c|c|c|}
\hline Nilai & Indikator sekolah & Indikator kelas \\
\hline Religius & $\begin{array}{l}\text { 1. Merayakan hari-hari besar keagamaan } \\
\text { 2. Memiliki fasilitas yang dapat } \\
\text { digunakan untuk beribadah } \\
\text { 3. Memberikan kesempatan kepada }\end{array}$ & $\begin{array}{l}\text { 1. } \begin{array}{l}\text { Berdo'a sebelum dan sesudah } \\
\text { pelajaran }\end{array} \\
\text { 2. } \\
\text { Memberikan kesempatan kepada } \\
\text { semua peserta didik untuk }\end{array}$ \\
\hline
\end{tabular}


Pedagogik Jurnal Pendidikan, Maret 2014, Volume 9 Nomor 1, (9-38)

\begin{tabular}{|c|c|c|}
\hline & $\begin{array}{l}\text { semua peserta didik } \\
\text { melaksanakan ibadah }\end{array}$ & melaksanakan ibadah \\
\hline Jujur & $\begin{array}{ll}\text { 1. } & \text { Menyediakan tempat temuan barang } \\
\text { hilang } \\
\text { Transparasi laporan keuangan dan } \\
\text { penilaian sekolah secara berkala } \\
\text { 3. Menyediakan kantin kejujuran } \\
\text { 4. Menyediakan kotak saran dan } \\
\text { pengaduan } \\
\text { 5. Larangan membawa failitas } \\
\text { komunikasi pada saat ulangan atau } \\
\text { ujian }\end{array}$ & $\begin{array}{ll}\text { 1. } & \text { Menyediakan fasilitas untuk } \\
\text { temuan barang hilang } \\
\text { 2. Transparasi laporan keuangan dan } \\
\text { penilaian kelas secara berkala } \\
\text { 3. Larangan menyontek }\end{array}$ \\
\hline Toleransi & $\begin{array}{l}\text { Menghargai dan memberikan pelakuan yang } \\
\text { sama terhadap seluruh warga sekolah tanpa } \\
\text { membedakan suku, agama, ras, status sosial, } \\
\text { status ekonomi, dan kemampuan khas }\end{array}$ & $\begin{array}{l}\text { 1. Memberikan pelayanan yang sama } \\
\text { terhadap seluruh warga kelas tanpa } \\
\text { membedakan suku, ras, golongan, } \\
\text { status sosial, dan status ekonom } \\
\text { 2. Memberikan pelayanan terhadap } \\
\text { anak berkebutuhan khusus } \\
\text { 3. Bekerja dalam kelomppok yang } \\
\text { berbeda }\end{array}$ \\
\hline Disiplin & $\begin{array}{l}\text { 1. Memiliki catatan kehadiran } \\
\text { 2. Memberikan penghargaan kepada } \\
\text { warga sekolah yang disiplin } \\
\text { 3. Memiliki tata tertib sekolah } \\
\text { 4. Membiasakan warga sekolah untuk } \\
\text { berdisiplin } \\
\text { 5. Menegakkan aturan dengan } \\
\text { memberikan sanksi secara adil begi } \\
\text { pelanggar tata tertib sekolah }\end{array}$ & $\begin{array}{l}\text { 1. Membiasakan hadir tepat waktu } \\
\text { 2. Membiasakan mematuhi aturan }\end{array}$ \\
\hline Kerja keras & $\begin{array}{l}\text { 1. Menciptakan suasana kompetisi yang } \\
\text { sehat } \\
\text { 2. Menciptakan suasana sekolah yang } \\
\text { menantang dan memacu untuk bekerja } \\
\text { keras } \\
\text { 3. Memiliki pajangan tentang slogan atau } \\
\text { moto tentang kerja }\end{array}$ & $\begin{array}{l}\text { 1. Suasana kompetisi } \\
\text { 2. Menciptakan kondisi etos kerja } \\
\text { 3. Menciptakan suasan belajar yang } \\
\text { memacu daya tahan kerja } \\
\text { 4. Memiliki slogan atau moto tentang } \\
\text { giat bekerja dan belajar }\end{array}$ \\
\hline Kreati & $\begin{array}{l}\text { Menciptakan situasi yang menumbuhkan } \\
\text { daya berpikir dan bertindak kreatif }\end{array}$ & $\begin{array}{l}\text { 1. Menciptakan situasi belajar yang } \\
\text { bisa menumbuhkan daya piker dan } \\
\text { bertindak kreatif } \\
\text { 2. Pemberian tugas yang menantang } \\
\text { memunculkan karya-karyabaru } \\
\text { baik yang autentik maupun } \\
\text { modifikasi }\end{array}$ \\
\hline Mandiri & $\begin{array}{l}\text { Menciptakan situasi sekolah yang } \\
\text { membangun kemandirian peserta didik }\end{array}$ & $\begin{array}{l}\text { Menciptakan suasana kelas yang } \\
\text { memberikan kesempatan kepada peserta } \\
\text { didik untuk bekerja mandiri }\end{array}$ \\
\hline Demokratis & $\begin{array}{l}\text { 1. Melibatkan kepala sekolah dalam } \\
\text { setiap pengambilan keputusan } \\
\text { 2. Menciptakan suasana sekolah yang } \\
\text { menerima perbedaan }\end{array}$ & $\begin{array}{l}\text { 1. Mengambil keputusan kelas secara } \\
\text { bersama melalui musyawarah dan } \\
\text { mufakat } \\
\text { 2. Pemilihan kepengurusan kelas } \\
\text { secara terbuka }\end{array}$ \\
\hline
\end{tabular}

*Nurul Hikmah Kartini, M.Pd Dosen FKIP Universitas Muhammadiyah Palangkaraya 


\begin{tabular}{|c|c|c|}
\hline & & $\begin{array}{l}\text { 3. Seluruh produk kebijakan melalui } \\
\text { musyawarah dan mufakat } \\
\text { 4. } \begin{array}{l}\text { Mengimplementasi model } \\
\text { pembelajaran yang dialogis dan } \\
\text { interaktif }\end{array}\end{array}$ \\
\hline $\begin{array}{l}\text { Rasa ingin } \\
\text { tahu }\end{array}$ & $\begin{array}{l}\text { 1. Menyediakan media komunikasi atau } \\
\text { informasi } \\
\text { 2. Memfasilitasi warga sekolah untuk } \\
\text { bereksplotasi dalam pendidikan, ilmu } \\
\text { pengetahuan, teknologi, dan budaya }\end{array}$ & $\begin{array}{l}\text { 1. Menciptakan suasana kelas yang } \\
\text { mengandung rasa ingin tahu } \\
\text { 2. Ekslporasi lingkungan secara } \\
\text { terprogram } \\
\text { 3. Tersedia media komunikasi atau } \\
\text { informasi }\end{array}$ \\
\hline $\begin{array}{l}\text { Semangat } \\
\text { kebangsaan }\end{array}$ & $\begin{array}{l}\text { 1. Melakukan upacara rutin di sekolah } \\
\text { 2. Melakukan upacara hari-hari besar } \\
\text { nasional } \\
\text { 3. Menyelenggarakan peringatan hari } \\
\text { kepahlawanan nasional } \\
\text { 4. Melakukan kunjungan ke tempat } \\
\text { bersejarah } \\
\text { 5. Mengikuti lomba pada hari besar } \\
\text { nasional }\end{array}$ & $\begin{array}{l}\text { 1. Bekerjasama dengan teman } \\
\text { sekelas yang berbeda suku, ras, } \\
\text { etnis, maupun budaya } \\
\text { 2. } \begin{array}{l}\text { Mediskusikan hari-hari besar } \\
\text { nasional }\end{array}\end{array}$ \\
\hline & $\begin{array}{l}\text { 1. Menggunakan produk dalam negeri } \\
\text { 2. Menggunakan bahasa Indonesia yang } \\
\text { baik dan benar } \\
\text { 3. Menyediakan informasi tentang } \\
\text { kekayaan alam dan budaya Indonesia }\end{array}$ & $\begin{array}{l}\text { 1. Memajangkan: foto presiden dan } \\
\text { wakil presiden, bendera Negara, } \\
\text { lambing Negara, peta Indonesia, } \\
\text { dan gambar kehidupan masyarakat } \\
\text { Indonesia } \\
\text { 2. } \begin{array}{l}\text { Menggunakan produk buatan } \\
\text { dalam negeri }\end{array}\end{array}$ \\
\hline Bersahabat/ & $\begin{array}{l}\text { 1. Suasana sekolah yang memudahkan } \\
\text { terjadinya interaksi antar warga } \\
\text { sekolah } \\
\text { 2. Berkomunikasi dengan bahasa yang } \\
\text { santun } \\
\text { 3. Saling menghargai dan menjaga } \\
\text { kehormatan } \\
\text { 4. Pergaulan dengan cinta kasih dan rela } \\
\text { berkorban }\end{array}$ & $\begin{array}{ll}\text { 1. } & \text { Pengaturan kelas yang } \\
\text { memudahkan terjadinya interaksi } \\
\text { peserta didik }\end{array}$ \\
\hline Cinta damai & $\begin{array}{l}\text { 1. Menciptakan suasana sekolah dan } \\
\text { bekerja yang nyaman, tentram, dan } \\
\text { harmonis } \\
\text { 2. Membiasakan prilaku warga sekolah } \\
\text { yang anti kekerasan } \\
\text { 3. Membiasakan prilaku warga sekolah } \\
\text { yang bias gender } \\
\text { 4. Perilaku seluruh warga sekolah yang } \\
\text { penuh kasih saying }\end{array}$ & $\begin{array}{l}\text { Menciptakan suasana kelas yang } \\
\text { damai } \\
\text { 2. Membiasakan prilaku warga } \\
\text { sekolah yang anti kekerasan } \\
\text { 3. Kekerabatan di kelas yang penuh } \\
\text { kasih saying }\end{array}$ \\
\hline $\begin{array}{l}\text { Gemar } \\
\text { membaca }\end{array}$ & $\begin{array}{l}\text { 1. Program wajib membaca } \\
\text { 2. Frekuensi kunjungan ke perpustakaan } \\
\text { 3. Menyediakan fasilitas dan suasana } \\
\text { menyebangkan untuk membaca }\end{array}$ & $\begin{array}{ll}\text { 1. } & \text { Daftar buku atau tulisan yang } \\
\text { dibaca peserta didik } & \\
\text { 2. } & \text { Frekuensi kunjungan } \\
\text { perpustakaan } \\
\text { 3. Saling tukar bacaan } \\
\text { 4. Pembelajaran yang memotivasi } \\
\text { peserta didik menggunakan }\end{array}$ \\
\hline
\end{tabular}


Pedagogik Jurnal Pendidikan, Maret 2014, Volume 9 Nomor 1, (9-38)

\begin{tabular}{|c|c|c|}
\hline & & referensi \\
\hline $\begin{array}{l}\text { Peduli } \\
\text { lingkungans }\end{array}$ & $\begin{array}{l}\text { 1. Pembiasaan memelihara kebersihan } \\
\text { dan kelestarian lingkungan sekolah } \\
\text { 2. Tersedia tempat pembuangansampah } \\
\text { dan tempat cuci tangan } \\
\text { 3. Menyediakan kamar mandi dan air } \\
\text { bersih } \\
\text { 4. Pembiasaan hemat energi } \\
\text { 5. Membuat biopori di area sekolah } \\
\text { 6. Membangun saluran limbah air } \\
\text { dengan baik } \\
\text { 7. Melakukan pembiasaan memisahkan } \\
\text { sampah organik dan non organik } \\
\text { 8. Penugasan pembuatan kompos dari } \\
\text { sampah organic } \\
\text { 9. Menyediakan peralatan kebersihan } \\
\text { 10. Membuat tandon penyimpanan air }\end{array}$ & $\begin{array}{l}\text { 1. Memelihara lingkungan kelas } \\
\text { 2. Tersedia tempat pembuangan } \\
\text { sampah di dalam kelas } \\
\text { 3. Pembiasaan hemat energi }\end{array}$ \\
\hline Peduli social & $\begin{array}{l}\text { 1. Memfasilitasi kegiatan bersifat sosial } \\
\text { 2. Melakukan aksi sosial } \\
\text { 3. Menyediakan fasilitas untuk } \\
\text { menyumbang }\end{array}$ & $\begin{array}{l}\text { 1. Berempati sesama teman kelas } \\
\text { 2. Melakukan aksi social } \\
\text { 3. Membangun kerukunan warga } \\
\text { kelas }\end{array}$ \\
\hline $\begin{array}{l}\text { Tanggung } \\
\text { jawab }\end{array}$ & $\begin{array}{l}\text { 1. Membuat laporan setiap kegiatan yang } \\
\text { dilakukan dalam bentuk lisan meupun } \\
\text { tertulis } \\
\text { 2. Melakukan tugas tanpa disuruh } \\
\text { 3. Menunjukkan prakarsa untuk } \\
\text { mengatasi masalah dalam lingkup } \\
\text { terdekat } \\
\text { 4. Menghindarkan kecurangan dalam } \\
\text { pelaksanaan tugas }\end{array}$ & $\begin{array}{l}\text { 1. Pelaksanaan tugas piket secara } \\
\text { teratur } \\
\text { 2. Peran serta aktif dalam kegiatan } \\
\text { sekolah } \\
\text { 3. Mengajukan usul pemecahan } \\
\text { masalah }\end{array}$ \\
\hline
\end{tabular}

Dari indikator-indikator di atas dapat dipahami bahwa, apabila semua indikator dapat dilaksanakan maka tentunya karakter peserta didik pasti akan dapat mengubah bangsa ini menjadi lebih baik lagi. Akan tetapi, semua ini perlu kerja keras dan dukungan dari semua pihak untuk mewujudkannya.

\section{SIMPULAN}

Pada bagian akhir penulisan ini, dikemukakan kesimpulan dan saran yang diambil berdasarkan analisis data tentang "Implementasi Pendidikan Karakter Terhadap Mata Pelajaran IPA (Studi Kasus
Kelas V Pada MIS Hidayatul Insan Palangka Raya)".

1. Kepala sekolah dan semua guru di MIS Hidayatul Insan Palangka Rayatertarik untuk terus menerapkan pendidikan karakter di sekolahnya. Karena dengan pendidikan karakter sikap dan prilaku peserta didik ketika mengikuti pembelajaran di dalam kelas maupun ketika bergaul di luar kelas sudah menunjukkan perubahan yang lebih baik dan diterapkan dalam kehidupan sehari-hari.

2. Faktor penghambatnya adalah guru di dalam pendidikan karakter ini hanya sebagai fasilitator saja, sehingga dalam 
proses pembelajarannya peserta didiklah yang harus berusaha memahami materi yang ada di buku, walaupun tidak menutup kemungkinan para guru juga masih menjelaskan materi di depan kelas. Jadi, kesimpulannya yang rajin semakin rajin dan pintar sebaliknya, yang malas semakin tertinggal dengan temannya. Tetapi, kami selaku guru di sekolah ini berusaha mengatasi masalah-masalah yang terjadi pada peserta didik, dengan selalu memberikan pengarahan dan motivasi kepada semua peserta didik untuk terus belajar dan mencoba dekat dengan semua sehingga kami tahu apa yang dibutuhkan oleh peserta didik.

3. Manfaat yang di dapat dari penerapan pendidikan karakter adalah:

a. Pada saat mengajar guru akan lebih mudah menguasai materi dan penggunaan media

b. Peserta didik akan lebih cepat memahami materi yang diajarkan oleh guru c. Peserta didik akan terbiasa berdisiplin

d. Peserta didik akan terbiasa menerapkan nilai-nilai pendidikan karakter dalam kehidupan seharihari

e. Peserta didik akan lebih kreatif, karena dalam pembelajaran pendidikan karakter (khususnya IPA) peserta didik harus bisa berdiskusi dan menemukan jawaban dari pertanyaan yang diberikan guru dengan sendiri dan guru hanya sebagai fasilitator

f. Antara peserta didik dan guru akan lebih menghormati dan menghargai

g. Dalam lingkungan sekolah akan tercipta suasana yang harmonis dan menyayangi

h. Dalam lingkungan sekolah akan tercipta interaksi sosial yang baik

i. Dapat meningkatkan hasil maupun prestasi belajar peserta didik

\section{DAFTAR PUSTAKA}

Adisusilo, Sutarjo (2012). Pembelajaran nilai-karakter, Jakarta: Rajawali. Bungin, Burhan (2007). Penelitian Kualitatif, Jakarta: Prenada Media Group.

Departemen Pendidikan Nasional Republik Indonesia, (2003). Undang-Undang Republick

Indonesia Tentang Sistem Pendidikan Nasional, Jakarta: Sekretariat Negara.

Departemen Pendidikan Nasional, (2012), Panduan Pengembangan Pendidikan Karakter, Jakarta: Tim Penulis

Emzir (2011). Metodologi Kualitatif Analisis Data, Jakarta: Rajawali Pers.

Herabudin (2010). Literasi IPA, Jakarta: Rineka cipta.

Megawangi, Ratna (2009). Menyemai Benih Karakter, Bogor: Indonesia Heritage

Foundation

Megawangi, Ratna (2004). Pendidikan Karakter, Bogor: Indonesia Heritage Foundation

Moleong, lexy. J (2000). Metode Penelitian Kualitatif: Bandung: Alfabeta

Nahartyo, Ertambang (2012). Desain Dan Implementasi Riset Eksperimen, Jogyakarta:

UPP STIM YKPN

Sahlan, A dan Prasetyo, A.T (2012). Desain Pembelajaran Berbasis Pendidikan Karakter,

Jogjakarta: Ar-Russ Media

Slameto (2010). Belajar dan Faktor-Faktor Yang Mempengaruhi, Jakarta: Rineka Cipta.

*Nurul Hikmah Kartini, M.Pd Dosen FKIP Universitas Muhammadiyah Palangkaraya 
Pedagogik Jurnal Pendidikan, Maret 2014, Volume 9 Nomor 1, (9-38)

Sugiyono (2010). Memahami Penelitian Kualitatif, Bandung: Alfabeta

Sugiyono (2011). Metode Penelitian Kuantitatif Kualitatif Dan $R \& D$, Bandung : Alfabeta Trianto (2010). Model Pembelajaran Terpadu, Jakarta. Bumi Aksara

Wati (2011). Pelaksanaan Kegiatan Ekstra Kurikuler, Palangkaraya: Universitas

Muhammadiyah Palangkaraya (UMP)

Wirotomo, Paulus (2011). Pendidikan Toleransi Bagian dari Karakter Bangsa. Jurnal Akrab, volume II. 14 